\title{
KEHIDUPAN PROSTITUSI DAN AGAMA (Studi Fenomenologi Pekerja Seks Komersial di Tanjung Bira Kab. Bulukumba)
}

\author{
Sam'un Mukramin ${ }^{1} \&$ Muhammad Nawir ${ }^{2}$ \\ ${ }^{1}$ Pendidikan Sosiologi, Universitas Muhammadiyah Makassar \\ Email: samun.mukramin@unismuh.ac.id \\ ${ }^{2}$ Pendidikan Sosiologi, Universitas Muhammadiyah Makassar \\ Email: muhammadnawir@unismuh.ac.id
}

\begin{abstract}
This research is a qualitative descriptive study using a phenomenological approach. Informants were determined by purposive sampling, based on the characteristics of the informants that had been determined, namely community leaders, local government and Commercial Sex Workers (CSW). Data collection techniques are observation, interview and documentation. The technique of analyzing data is through various stages, namely data reduction, data presentation and conclusion drawing, while the data validation technique uses source, time, and technique triangulation. The purpose of this study was i) to find out the public response to the presence of prostitution sites in Tanjung Bira District, Bulukumba. ii) knowing how the religious life of CSW in the world of prostitution. The results of this study indicate that, i) the majority of Bira villagers reject the presence of prostitution because it is considered to be only a negative impact, but there are also those who accept the presence of prostitus due to benefits ii) CSW also need people in the world of belief go to places of worship join in religious events that are considered important and also carry out religious acts such as fasting in the holy month of Ramadan, giving alms, paying zakat and performing Eid prayer
\end{abstract}

Keywords: Life, Prostitution and Religion

Abstrak. Penelitian ini adalah penelitian deskriptif kualitatif dengan menggunakan pendekatan fenemonologis. Informan ditentukan dengan cara purpusive sampling, berdasarkan karakteristik informan yang telah ditentukan yaitu tokoh masyarakat, pemerintah setempat dan Pekerja Seks Komersial (PSK). Teknik pengumpulan data yaitu observasi, wawancara dan dokumentasi. Teknik analisis data melalui berbagai tahapan yaitu reduksi data, penyajian data dan penarikan kesimpulan, sedangkan teknik keabsahan data menggunakan tringulasi sumber, waktu, dan teknik. Tujuan penelitian ini adalah i) mengetahui respon masyarakat terhadap kehadiran tempat prostitusi di Tanjung Bira Kab. Bulukumba. ii) mengetahui bagaimana kehidupan keberagamaan para PSK dalam dunia prostitusi Hasil penelitian ini menunjukkan bahwa, i) masyarakat desa Bira sebagian besar menolak kehadiran tempat prostitusi karena dianggap hanya akan mendatang dampat negatif, namun ada juga yang menerima kehadiran tempat prostitus karena mendapatkan keuntungan ii) PSK juga manusia yang butuh pada dunia keyakinan, mereka juga sering mendatangi tempat ibadah ikut pada acara-acara keagamaan yang dianggap penting dan juga melakukan tindakan-tindakan keagamaan seperti berpuasa dibulan suci ramadhan, bersedekah, membayar zakat dan melaksanakan shalat idul fitri.

Kata Kunci : Kehidupan, Prostitusi dan Agama 


\section{PENDAHULUAN}

Dunia prostitusi melambangkan kemenduan pandangan dan sikap masyarakat. Di satu sisi mereka yang terlibat langsung maupun tidak langsung dalam dunia ini dihujat, diumpat dan direndahkan, dan pada sisi lain kehadirannya dibutuhkan bahkan tidak sedikit yang menikmatinya. Dan yang paling terpuruk dan mengalami marginalisasi dan bahkan dikorbankan dalam dunia prostitusi ini adalah kaum perempuan. Perempuan dengan daya seksualitasnya cenderung mengalami eksploitasi dari jejaring kuasa relasi gender yang timpang dalam masyarakat kita. Prostitusi merupakan fenomena yang sudah ada sejak lama ada di dunia tak terkecuali di Indonesia. Banyak hal yang menyebabkan praktek postitusi tetap eksis sampai hari ini, diantaranya disebabkan oleh nafsu seks yang abnormal, broken home, korban pemerkosaan, adanya ambisi-ambisi besar pada diri wanita untuk mendapatkan status sosial yang tinggi dengan jalan yang mudah tanpa kerja keras, dijual oleh keluarganya sendiri, terbawa oleh pergaulan, tekanan ekonomi sehingga menghalalkan segala cara agar kebutuhan ekonominya terpenuhi.

Bulukumba yang merupakan salah satu Daerah di Sulawesi Selatan yang memiliki banyak tempat wisata tidak terlepas dari praktek prostitusi. Salah satu tempat wisata yang terkenal di Kabupaten Bulukumba adalah Tanjung Bira. Tanjung Bira terkenal dengan pantai pasir putihnya yang cantik dan menyenangkan. Airnya jernih, baik untuk tempat berenang dan berjemur. Di sini kita dapat menikmati matahari terbit dan terbenam dengan cahayanya yang berkilau terbersit pada hamparan pasir putih sepanjang puluhan kilometer. Tanjung Bira yang sudah terkenal hingga manca negara turis-turis Asing dari berbagai negara banyak yang berkunjung ke tempat ini untuk berlibur, kini juga Tanjung Bira sudah ditata secara rapi menjadi kawasan wisata yang patut diandalkan. Berbagai sarana sudah tersedia, seperti perhotelan, restoran, serta sarana telekomunikasi, Tanjung Bira berlokasi sekitar $41 \mathrm{Km}$ kearah Timur dari kota Bulukumba. Secara historis, prostitusi yang ada di Tanjung Bira memiliki sejarah yang panjang, prostitusi telah menjadi bagian yang tak terpisahkan dari kehidupan masyarakat. Pekerja Seks Komersial (PSK) yang ada di Tanjung Bira berbeda halnya dengan PSK yang ada di tempat lain, PSK yang ada di Tanjung Bira umumnya melayani tamu dengan minuman, mereka tidak serta merta dipajang didepan kemudian pelanggan datang dan memilih perempuan mana yang akan ditemani untuk berkencan. 
Para wanita yang bekerja sebagai PSK di Tanjung Bira umumnya berasal dari luar Daerah Kabupaten Bulukumba, mereka berasal dari berbagai Daerah di Sulawesi Selatan dan bahkan dari mereka ada yang berasal dari Jawa, Sumatera, dan Kalimantan dan dari berbagai Kota lainnya di Indonesia. Profesi sebagai PSK seringkali dikaitkan dengan hal yang negatif yaitu tentang penyakit sosial yang mengganggu ketertiban dan keindahan Tanjung Bira. Sehingga sebagian masyarakat menganggap bahwa tempat prostitusi hanya memberikan dampak buruk bagi masyarakat dan merusak nama Kabupaten Bulukumba. Maka dari uraian di atas penulis tertarik melakukan penelitian tentang "Agama dalam Kehidupan Prostitusi (studi Fenemologis PSK Tanjung Bira Kab. Bulukumba)".

\section{METODE PENELITIAN}

Data yang digunakan dalam penelitian ini adalah deskriptif-kualitatif, karena bertujuan untuk memperoleh gambaran secara mendalam tentang agama dalam kehidupan prostitusi di Tanjung Bira Kab. Bulukumba. Meleong (2011: 3), menjelaskan bahwa "metode kualitatif sebagai prosedur penelitian yang menghasilkan data deskriptif berupa kata-kata tertulis atau lisan dari orang-orang dan perilaku yang dapat diamati. Pendekatan ini diarahkan pada latar dan individu tersebut secara holistik (utuh)". Sedangkan Rianse \& Abdi (2009:9) "Penelitian kualitatif berupaya memberikan penggambaran secara mendalam tentang situasi yang diteliti".

Pendekatan kualitatif cenderung menggunakan analisis induktif, di mana dalam proses penelitian dan pemberian makna terhadap data dan informasi yang lebih ditonjolkan dengan ciri utama pendekatan ini adalah fenomenologis, tujuan dari penelitian fenemologis adalah mencari atau menemukan makna dari hal hal yang esensial atau mendasar dari pengalaman hidup tersebut. Sehingga penelitian kualitatif dapat di desain untuk memberikan bantuannya terhadap teori, praktis, kebijakan, tindakan dan masalah sosial. Dalam hal ini, untuk memudahkan observasi/pengamatan dan konseptualisasi fokus penelitian, maka fokus tersebut perlu dideskripsikan secara kongkrit. Dalam menentukan seorang informan, peneliti melakukan teknik purposive sampling atau pengambilan sampel secara sengaja yang sesuai dengan persyaratan sampel yang diperlukan dengan 
pertimbangan tertentu dan sebagai salah satu teknik dalam penelitian yang bersifat kualitatif.

\section{HASIL DAN PEMBAHASAN}

\section{Respon Masyarakat Terhadap Kehadiran Tempat Prostitusi di Tanjung Bira}

Prostitusi merupakan permasalahan yang sangat kompleks karena menyangkut berbagai aspek kehidupan masyarakat. Kegiatan pelacuran menyangkut aspek sosial, gender, hukum, kesehatan, moral dan etika, agama, pendidikan, psikologis, ekonomi, industrialisasi dan juga politik. Praktek prostitusi sudah berkembang dimana-mana hampir disetiap kabupaten/kota kita jumpai praktek prostitusi, hal ini sangat banyak mempengaruhi kehidupan masyarakat terutama masyarakat sekitar lingkungan tempat prostitusi serta mental pemuda sebagai generasi penerus bangsa, karena sebagian besar praktek prostitusi dijadikan sebagai jalan terakhir dalam mencari penghasilan.

Prostitusi bukanlah masalah baru yang ada dalam sebuah masyarakat tapi masalah lama yang diwariskan oleh nenek moyang kita sebagai sebuah kebudayaan yang sepertinya harus kita lestarikan. Inilah salah satu doktrin yang ada dalam masyarakat kita diantara sekian banyak doktrin yang dipakai untuk melestarikan kebudayaan prostitusi tersebut, banyak dikalangan kita yang menganggap prostitusi adalah masalah sosial yang tidak bisa dihilangkan karna dia ada disetiap zaman dan yang harus dilakukan adalah melokalisasikan prostitusi tersebut sehingga dampak yang ditimbulkan bisa diantisipasi. Tapi ada juga yang menganggap prostitusi harus dihilangkan dari permukaan bumi ini, karna prostitusi salah satu penyakit yang dapat merusak moral generasi bangsa yang tentunya berbagai macam cara yang ditawarkan untuk mengatasi hal tersebut.

Seiring dengan pertumbuhan dan perubahan secara primer, sekunder dan psikis pada remaja kearah kematangan yang sempurna, muncul juga hasrat dorongan untuk menyalurkan dorongan seksualnya. Hal tersebut merupakan suatu hal yang wajar karena secara alamiah dorongan seksual ini memang harus terjadi untuk menyalurkan kasih sayang antara dua insan, sebagai fungsi pengembangbiakan dan mempertahankan keturunan. Prostitusi merupakan salah satu bentuk penyakit masyarakat yang harus dihentikan penyebarannya tanpa mengabaikan usaha pencegahan dan perbaikan. Prostitusi berasal 
dari bahasa latin pro-stituere atau pro-stauree, yang berarti membiarkan diri berbuat zina, melakukan persundalan, dan percabulan. Sedangkan prostitute adalah pelacur atau sundal. Dikenal pula dengan istilah PSK atau pekerja seks komersial.

Prostitusi adalah sebuah fenomena yang tidak sesuai dengan norma yang belaku di dalam masyarakat baik itu norma agama maupun norma adat istiadat, khusunya masyarakat Desa Bira yang memegang teguh. Norma agama adalah aturan yang bersumber dari Tuhan Yang Maha Esa. Norma Agama pada dasarnya sangat melarang keras adanya praktek pelacuran karena itu sama saja menghalalkan perzinahan sementara agama islam sangat melarang hal tersebut, perzinahan itu merupakan suatu perbuatan yang keji, tidak sopan dan jalan yang buruk. Sebagaimana dijelaskan dalam surat Al-Isra ayat 32 menyebutkan:

Artinya: "Dan janganlah kamu mendekati zina; Sesungguhnya zina itu adalah suatu perbuatan yang keji. dan suatu jalan yang buruk".

Sangat jelas bahwa, prostitusi dalam agama khususnya Agama Islam sangat melarang tempat prostitusi sebab melanggar kesopanan, merusak keturunan, menyebabkan penyakit kotor, menimbulkan persengketaan, ketidak rukunan dalam keluarga, dan malapetaka lainnya. Selanjutnya "Perempuan yang melakukan hubungan intim dengan laki-laki yang bukan mahramnya sebaiknya dihukum sesuai dengan hukum Allah Ta'ala tanpa harus merasa kasihan kepadanya ketika melaksanakan hukumna Allah Ta'ala. Sebagaimana dijelaskan dalam Al-Qur'an dalam surat An-Nur ayat 2 yang menyatakan pelarangan bunyinya sebagai beriku:

Artinya: "Perempuan yang berzina dan laki-laki yang berzina, Maka deralah tiap-tiap seorang dari keduanya seratus kali dera, dan janganlah belas kasihan kepada keduanya mencegah kamu untuk (menjalankan) agama Allah, jika kamu beriman kepada Allah, dan hari akhirat, dan hendaklah (pelaksanaan) hukuman mereka disaksikan oleh sekumpulan orang-orang yang beriman".

Dengan demikian bahwa pada dasar perempuan dan laki-laki yang terlibat dalam praktek prostitusi maka sebaiknya mereka didera seratus kali dan tanpa ada belas kasihan. Hukuman atau sangsi yang di berikan kepada pezina hendaknya pula disaksikan oleh banyak orang terutama oleh sekumpulan orang-orang yang beriman. Norma adat pada galibnya melarang prostitusi. Akan tetapi, setiap daerah itu tidak sama peraturanya; dan kebanyakan 
norma tersebut tidak tertulis. Pelarangan prostitusi itu berdasarkan alasan sebagai berikut; tidak menghargai diri wanita, diri sendiri, penghinaan terhadap isteri dan pria-pria yang melacurkan diri, tidak menghomati kesucian perkelaminan, menyebabkan penyebaran penyakit kotor dan menular serta mengganggu keserasian perkawinan

Kabupaten Bulukumba sangat kental dengan adatnya, seperti halnya di tanah toa kajang, di desa Bira juga mempunyai adat yang sangat dijungjung tinggi oleh masyarakat sekitar. Mungkin kita masih ingat atau pernah mendengar kisah Karaeng Tiro yang di bawa lari anaknya karena persoalan hamil di luar nikah, kemudian Karaeng Tiro menyuruh anaknya Andi Aso saudara Andi Tenri untuk membunuh orang yang yang membawa lari Andi Tenri karena persoalan siri atau malu. Begitu hal dengan prostitusi yang ada di desa Bira, itu sangat bertentangan dengan adat istiadat masyarakat setemapat. Prostitusi adalah perbuatan yang dilarang oleh Agama dan Adat (adat Bira) sebab itu dapat mendatangkan masalah dan penyakit yang sangat berbahaya.

"Gitte ri bira nilarangki angjo tampa maksiatka nasaba anre nasicoco adatka, riolopa-nariolo niharanganggi, minka liniapami nasaba takkala riemi na pamarentah kuitte anreja napeduliki, nasareji pole isin. Riolo gitte anre narie anukamma enjo nasaba riepertahanngki adakka, sirikki punna rie nupakamma enjo ri kampong".

Artinya: Dulu kita di bira sangat dilarang itu tempat maksiat, sebab sanagat bertentangan dengan adat istiadat yang ada tapi apa boleh buat semuaya sudah terjadi, pemerintah juga tidak peduli dengan dengan adat yang berlaku dari dulu malah dia member isin kepada mereka untuk membangun dan mengelolahnya, dulu kita malu kalau kita malu kalau ada tempat seperti itu sebab di pertahankan adat, kita malu jika terdapat tempat maksiat di daerah kita.

Kehadiran tempat prostitusi di Tanjung Bira buka hanya mendatangkan dampak yang negatif tetapi juga mendatangkan dampak positif, kehadiran Bar dan Cafe membuka lapangan kerja bagi masyarakat sekitar dan mampu meningkatkan kesejahteraan mereka misalnya saja di sekitar tempat prostitusi banyak masyarakat yang membuka Kios-kios untuk berjualan, warung dan sebagainya, dan bagi anak muda banyak yang bekerja di Bar dan Cafe 
tersebut. Namun disisi lain, kehadiran tempat prostitusi juga mendatangkan income bagi sebagian orang

"Tempat Bar sangat mendatangkan rejeki bagi kami penduduk desa Bira, sebab dengan adanya tempat bar tersebut kami dapat bekerja dan bisa menghasilkan dan mendapatkan pendpatan sendiri tidak lagi mengandalkan orang tua sebagai pencari rejeki. Orang tua cukup tinggal saja dirumah menikmati hasil kerja kami, walaupun orang tua saya tidak setuju kerja ditempat Bar tersebut tapi maumi diapaiii takkalami. Kah anre jaman-jaman maraeng (tidak ada pekerjaan (ain)".

Bagi yang bekerja sebagai pegawai Bar bahwa dia setuju dengan adanya tempat dan operasinya Bar tersebut sebab dapat mendatangkan rejeki dan dapat menekan angka pengangguran di desa Bira walaupun dilarang oleh orang tua bekerja di temnpat tersebut. Bar yang ada di Bulukumba tepatnya di Desa Bira Kecamatan Bonto Bahari pada mulanya hanya ada tiga dan tempatnya berada di Dermaga pintu masuk pelabuhan Bira, namun seiring berkembangnya waktu dan semakin diminatinya tempat pariwisata Tanjung Bira membuat bar ini semakin berkembang menjadi 15 buah. Tempat yang digunakan bukan lagi di dekat dermaga atau pelabuhan melaikan mereka pindah keatas dekat gunung, yaitu di hutan dusun Birakeke. Mereka pindah bukan karena diusir oleh masyarakat atau pemerintah, akan tetapi adanya tekanan-tekana psikologis yang diberikan oleh warga yang membuat mereka berpindah tempat.

Secara sosiologis, prostitusi sebagai bagian dari fenomena sosial kemasyarakatan merupakan bagian dari permasalahan hidup dalam masyarakat dan semua harus menerima hal tersebut tanpa harus berdebat kusir apalagi menjadi berita di media massa karena prostitusi akan selalu ada tanpa kita tau dari mana asalnya dan kapan berakhirnya, dia akan selalu ada seiring dengan perkembangan suatu daerah dan begitu banyaknya masyarakat yang miskin sementara lapangan pekerjaan sangat minim atau sedikit. Menjadi PSK merupakan sebuah pilihan hidup seseorang tanpa ada paksaan. Profesi ini memiliki kesamaan dengan profesi lainnya yang membutuhkan keterampila, keberanian, dan pengalaman. Seorang pelacur dapat diibaratkan seperti naik ginung terjal dengan pelan sekali tetapi turunya cepat drastis dan akan habis dimakan waktu. 


\section{Kehidupan Agama PSK dalam Dunia Prostitusi}

Agama sebagai bagian dari pengalaman pribadi memberikan pemahaman dan makna yang berbeda-beda terhadap penganutnya. Walaupun sama agama dan dasar keyakinannya, setiap pemeluk agama memiliki perasaan tentang Tuhan yang berbeda-beda. Pada dasarnya paling relatif dari agama manapun, termasuk yang paling terlembagakan seperti agama Islam, Katolik, Protestan dan lain-lain adalah pemaknaan tentang Tuhan yang berbeda-beda.

Pekerja seks komersial sebagai profesi sebenarnya melambangkan perwajahan sesungguhnya dari pergulatan kuasa politik, ekonomi, budaya, dan moral di dalam masyarakat. PSK adalah orang-orang yang terlempar dari pergulatan kuasa sehingga mengalami ketidakberuntungan nasib dan kehidupan yang tersudut secara sosial, budaya bahkan politik. Hampir secara keseluruhan kajian tentang prostitusi menunjukkan bahwa menjadi PSK pilihan terakhir yang disertai dengan keterpaksaan dari para aktor yang menjalaninya.

Dunia prostitusi melambangkan kemenduan pandangan dan sikap masyarakat. Di satu sisi mereka yang terlibat langsung maupun tidak langsung dalam dunia ini dihujat, diumpat dan direndahkan, dan pada sisi lain kehadirannya dibutuhkan bahkan tidak sedikit yang menikmatinya. Dan yang paling terpuruk dan mengalami marginalisasi dan bahkan di korbankan dalam dunia prostitusi ini adalah kaum perempuan. Perempuan dengan daya seksualitasnya cenderung mengalami eksploitasi dari jejaring kuasa relasi gender yang timpang dalam masyarakat kita.

Pekerja seks komersial juga manusia. Mereka bagian dari masyarakat, ketika manusia lain membutuhkan kehidupan dunia profan-materil dan juga dunia sakral kerohanian, sesungguhnya mereka juga sama. Di dalam kehidupan ini tidak ada seorang pun yang tidak memiliki kebutuhan tentang kehidupan kebersamaan/Ketuhanan. Hanya saja ada Tuhan yang diinstitusionalkan dalam bentuk agama dan ada pula yang tidak diinstitusionalkan. Akan tetapi jika mengikuti konsep kebutuhan asasi manusia maka berketuhanan adalah bagian dari kebutuhan dasar manusia dalam kehidupan, selain 
tentunya kebutuhan biologis dan sosial. la merupakan kebutuhan integratif yang merupakan aneka kebutuhan manusia di dalam pemenuhan hasrat kerohaniannya, bahkan di saat-saat tertentu, kebutuhan keronian jauh melebihi kebutuhan lainnya, terutama dikala manusia sedang menghadapi persoalan yang secara akal tidak mampu dipecahkannya.

Daerah pariwisata selalu menjadi alat yang mendatangkan tempat-tempat prostitusi, dari mana mereka datang dan sampai berprofesi sebagai PSK terkadang menimbulkan tanda tanya yang besar. Mereka sangat mudah untuk datang untuk meghilangkan atau melenyapkan sangatlah susah bahkan tidak mungkin diberantas dari muka bumi ini, sebab selama masih ada nafsu-nafsu seks yang lepas dari kendali kemauan dan hati nurani maka prostitusi itu akan tetap selalu ada. Timbulnya tempat prostitusi sebagai masalah social yaitu sejak adanya penataan relasi seks dan diberlakukannya norma-norma perkawinan.

Dibawah ini adalah motif yang menyebabkan sehingga seseorang melacurkan diri (Reno Bachtiar dan Edy Purnomo 2007) antara lain: Faktor ekonomi, Faktor kemalasan, Faktor pendidikan, Faktor persaingan, Faktor sakit hati, dan Tuntutan keluarga. Sebagi profesi, prostitusi adalah bagian kecil dari komunitas sosial, dan seperti komunitas lainnya, yang menghendaki kewajaran hidup, citra baik, pandangan yang jernih, baik dalam ruang struktural sosial, budaya dan agama. PSK tetap merindukan hidup normal seperti kebanyakan orang yang kebetulan beruntung nasibnya dan tidak mengalami sendu lara menjadi seorang PSK. Sebagaimana kebanyakan orang, juga ingin patuh pada hukum, konsensus-konsensus sosial dan kehendak Tuhan. Di sisi lain, mereka juga tertarik dan berharap dengan berimajinasi tentang ampunan Tuhan yang sangat luas dan tak terbatas. Mereka ingin sampai pada samudera pengampunan itu dan hidup normal, namun takdir meraka. Mereka hanya bungkam dalam gairah spiritual yang menggebu, sembari terus menyelami dunia hitam.

Pada dasarnya mereka tetap percaya dan menginginkan bisa terlepas dari dunia prostitusi dengan cara ada yang mengentaskan mereka dari tempat prostitusi perilaku keberagamaan yang mereka jalani dimana mereka merasa cemas ketika meninggalkan shalat dan merasa tentram ketika melaksanakan perintah agama. Kita itu bekerja ditempat merasa tertekan jaki juga karena banyak yang kita pikir, kita pikir dosanya, penilaian orang 
terhadap kita, apalagi kalau sama laki-laki yang belum kita kenal pasti lain-lain, makanya kalau bulan ramadhan saya pulangka kasi tenang pikiran sama keluarga, beribadah dibulan suci, kadang juga saya bersedekah kalau ada rejeki lebih.

\section{Agama dalam Kehidupan Prostitusi sebagai Dramaturgi Transedental}

Pekerjaan yang mereka jalani selama ini membuat dirinya tertekan, disatu sisi mereka merasa berdosa karena mereka juga memahami bahwa profesinya dilarang oleh agama dan mereka juga sering memikirkan pandangan masyarakat tentang pekerjaan yang mereka jalani, tetapi demi memenuhi kehidupan keluarganya WI terpaksa terus melakukan itu sembari menunggu keajaiban untuk mendapatkan kehidupan yang lebih baik. Tidak sedikit diantara mereka yang menuturkan bahwa pekerjaan yang ia jalani sebagai PSK tanpa sepengatahuan keluarganya, sepengetahuan pihak keluarga dia bekerja sebagai pembantu rumah tangga di kota Kab. Bulukumba. Seperti yang ia katakan

"Tidak ada yang tau keluargaku kalau saya bekerja sebagai PSK yang dia tau saya bekerja sebagai pembantu rumah tangga di kota Bulukumba".

Tidak sedikit pula PSK yang ingin keluar dari lembah hitam tersebut, dia mempunyai keinginan untuk mendapatkan pekerjaan yang lebih dan bisa berkumpul bersama keluarganya, dia tidak ingin hidupnya dihabiskan ditempat prostitusi, dia juga menginginkan hidupnya dijalani dengan hal-hal yang positif dan bermanfaat dan lebih mendekatkan diri kepada Tuhan. Karena bekerja sebagai prostitusi tidak saja merenggut kemanusiannya, tapi telah sedemikian sadis, menihilkan segala potensi aktual yang dimiliki perempuan; harga diri, harapa hidup, kemapanan bahkan spiritualitasnya pun dikebiri. Boleh orang menduga, mereka telah kehilangan segalanya; kehormatan, masa depan yang normal, keselamatan jiwa, namun tidak dengan spiritualitasnya. Psk tidak serta merta kehilangan Tuhan. Di saat semua kuasa dalam konstruksi sosial menyudutkan dan membuangnya, ada kuasa lain jau lebih besar yang terus meliputinya dan dapat menerima kehadirannya, tempat mendengarkan keluh kesahnya, menjadi peneguh saat mengalami keputusasaan, dan menjadi sandaran harap untuk sebuah keajaiban. Inilah kuasa Tuhan yang ada masih tersisa dalam imajinasi spiritual para PSK. 
Teori dramaturgi di kembangkan oleh Erving goffman. Karya goffman yang paling monumental adalah prentation of self in everday (1959). Dalam teori dramaturgi terdapat konsep front stag dan back stage. Gambaran yang bisa ditarik dari pemikiran Goffman adalah bahwa selalu ada tindakan imitasi yang di perankan oleh sang aktor di dalam interaksinaya dengan individu lain. Kehidupan para PSK adalah gambaran adanya ketegangan antara apa yang di tampilkan dan apa yang sesungguhnya terjadi. Gincu yang merah merekah tidak selalu menggambarkan bibir yang sebenarnya. Bisa saja bibir itu berwarna coklat, hitam. Bibir merah meronah yang di pampang oleh pelacur adalah contoh bahwa kehidupan tidak selalu seperti apa yang di sangkakan orang. Kebanyakan orang hanya melihat sesuatu dari tampilan luarnya saja (outword appearence) dan menafikkan dimensi terdalam (inward appearence). Tampilan fisik dan setting sosial tersebut bersatu menjadi dasar bagi orang lain untuk mengkonstruksi PSK dan dunianya. Dunia panggung belakang (back stage) merupakan dunia yang tersembunyi.

\section{KESIMPULAN}

Berdasarkan hasil penelitian mengenai Agama dalam Kehidupan Prostitusi di Tanjung Bira Kecamatan Bonto Bahari Kabupaten Bulukumba, sebagai berikut:

1. Kehadiran tempat prostitusi di Tanjung Bira menimbulkan respon yang bervariatif, sebagiam besar masyarakat menolak hadirnya tempat prostitusi karena mereka menganggap bahwa prostitusi dapat merusak dan hanya memberikan dampak negatif, ada pula sebagian masyarakat yang menerima kehadiran tempat prostitusi karena memberikan keuntungan bagi dirinya dan ada juga yang acuh tak acuh terhadap kehadiran tempat prostitusi

2. Dimensi kemanusiaan PSK perlu diperhatikan dengan cara empati, sebab PSK juga manusia yang memiliki spiritualitas dan bahasa tersendiri dalam mengapresiasi berdialog dengan Tuhan. PSK juga sering mengikuti upara keagamaan yang dianggap penting dan juga sering melakukan tindakan-tidakan keagamaan.

\section{DAFTAR PUSTAKA}

Alam, A. S. (1984). Pelacuran dan Pemerasan Studi Sosiologis tentang Eksploitasi Manusia oleh Manusia.. Ctk. Pertama, Alumni, Bandung.

Adiningsih, N.U. (2004). Virgin, remaja putri dan ancaman AIDS.

Amiruddin Arani. (2002). Tubuh, seksualitas dan kedaulatan perempuan. Yogyakarta: LKIS. 
Bachtiar, Reno dan Purnomo, Edy. (2007). Bisnis Prostitusi Profesi yang Menguntungkan. Yokyakarta: penerbit Pinus.

lip Wijayanto. (2003). Pemerkosaan Atas Nama Cinta, Ctk. Pertama, Tinta, Yokyakarta.

Hendropuspito. (2000). Sosiologi Sementik. Kanisius. Yogyakarta.

(2003). Sexin the "kost", Ctk Kedua, Tinta, Yogyakarta

Wuryo, K., Sjaifullah, A. (1983). Pengantar ilmu jiwa sosial. Jakarta: Penerbit Erlangga.

Kartono, K. (1981). Patologi sosial. Jakarta: Penerbit CV Rajawali.

Kartasapoetra, G dan R.G Widyaningsih. (1982). Teori Sosiologi. Armico : Bandung.

Koentjoro, Ph.D., (2004) Tutur Dari Sarang Pelacur, Yogyakarta : Tinta.

Manuaba, Ida Bagus Gde. (1999). Memahami Kesehatan Reproduksi Wanita. Jakarta: Arcan.

Munti, Ratna Batara. (2005). Demokrasi Keintiman: Seksualitas di Era Globalisasi. LKIS Yogjakarta: Yogjakarta.

Moleong, Lexy. (2003). Metodologi Penelitian Kualitatif. Bandung: Remaja Rosdakarya.

Nur, Syam. (2010). "Agama Pelacur" Dramaturgi Transedental. Yogyakarta: LKIS Printing Cemerlang.

Prastowo, Andi, (2011). Metode Penelitin Kualitatif dalam Perspektif Rancangan Penelitian. Jogjakarta: Ar-Ruzz Media.

Rahayuningsih, Sri Utami (2008) Psikologi Umum. Jakarta.

Sarwono, Sarlito Wirawan. 2002. Psikologi Sosial: Individu dan Teori-Teori Psikologi Sosial. Jakarta: Balai Pustaka.

Rianse, Usman \& Abdi, 2009. Metodologi Penelitian Sosial dan Ekonomi (Teori dan Aplikasi). Bandung: Alfabeta.

Rusdiyanti, Ana. (2008). Fenomena Prostitusi di Desa Awang-Awang Kec. Mojokerto: Jurusan Sosiologi. Yogyakarta: Universitas Gajah Mada.

Sundari. (2010). Dampak Lokalisai Morosoneng Pada Kehidupan Sosial Ekonomi Masyarakat Kecamatan Benowo Surabaya: Jurusan Sosiologi. Yogyakarta: Universitas Gajah Mada 